\title{
Why Multinationals Help Reduce Poverty ${ }^{1}$
}

\author{
Jagdish Bhagwati \\ Columbia University
}

\section{INTRODUCTION}

跑 ONOURING Baloo, as the many teachers, students and friends of V. N. Balasubramanyam fondly call him, is not difficult. I have known him from over 40 years ago, having encountered him first and discovered his talents when he became my Research Associate in India. Having interacted with him ever since in a career marked by policy-related research accomplishment of the highest order, I can truthfully claim that the gain from our friendship has been all mine.

The best way for me to honour him is to address the issues which have been most noteworthy in his research. These relate to the questions raised by multinationals where he is one of the most influential scholars today. There is virtually no international conference of any repute on multinationals where Baloo has not been invited and makes a notable contribution. I have profited from his persuasive writings on the need for an Investment Code at the WTO. I have also been delighted and educated by his demonstration (with his colleagues Sapford and Salisu) of the validity of my hypotheses that (i) inward-looking countries would ultimately attract lower foreign investment than outwardlooking countries and (ii) that the former investment would be less productive than the latter. ${ }^{2}$

In addition, his research has touched on most of the questions raised by the foes and friends of multinationals; and one cannot write on the subject without referring to Baloo's research. Let me begin with the conventional complaints

\footnotetext{
${ }^{1}$ In writing this article, I have drawn on some of my earlier writings on multinationals and, in particular, on my treatment of the subject in my recent book, In Defense of Globalization (Bhagwati, 2004).

${ }^{2}$ See Balasubramanyam et al. (1996).
} 
about their allegedly baleful influence on the well-being of poor countries and again of the poor among them.

\section{CHARGE-SHEET AGAINST MULTINATIONALS}

Critics tend to argue that multinationals must be condemned because they bypass several countries such as those in Africa that need them, often accentuating the 'divide' between those who are fortunate and those who are not. Then they also complain inconsistently that multinationals cause harm where they go, exploiting the 'host' countries and their workers.

The complaint about bypassing needy countries seems to be misplaced. If multinationals bypass some poor countries, that is surely not surprising. They are businesses that must survive by making a profit. Indeed, no corporation ever managed to do sustained good by making continuing losses. If a country wants to attract investment, it obviously has to be an attractive locale. That generally implies having political stability and economic advantages such as cheap labour or exploitable natural resources. In the game of attracting investment, therefore, some countries are simply going to lose because they lack these attributes.

For these unfortunate countries, the harsh reality is that no matter how good their politics and policies are, they may not suffice to attract multinationals. For these countries, the only answer is to offset this private neglect by redirecting public aid and technical assistance to them so that they get the funds and know-how that will not come through the marketplace. The problem, of course, is that if these countries lack the attributes necessary to attract multinationals, the likelihood of their being able to absorb aid funds productively is also limited: a problem that knee-jerk aid proponents today such as my colleague Jeffrey Sachs ignore to the detriment of these countries themselves since aid wasted, or siphoned off into corruption, will imperil their progress yet further.

The real battle is being fought, however, over the multinationals who do go in to the poor countries. Ironically, the complaint of the early developmen economists in the 1950s, chiefly Hans Singer, was that multinationals created enclaves and that there were no spillover effects, good or bad, for host countries. Their complaint was then similar to that of the critics who bemoan the fact that multinationals pass several countries by, except that the bypassing is now within the host country. There was probably something, but almost never enough, to this observation when the multinationals were in extractive industries. Today, however, manufacturing, and increasingly financial and other services, attract far more investment. The debate therefore has become acute between those who consider multinationals to be a malign influence and those who find it to be a benign force. As it happens, the evidence strongly suggests that the benign view is more persuasive. 


\section{HARMFUL EFFECTS?}

\section{a. Tax Competition}

Many observers of tax breaks to attract multinationals fear that there is a 'race to the bottom' on tax concessions as poor countries compete among themselves to give such generous terms to foreign investors that they wind up net losers. That, in fact, the race is so fierce that poor countries wind up net losers is doubtful. Even the concessions are from taxes which must be paid and which provide a presumption that multinationals earn for themselves less than what they contribute, the difference being the taxes paid. What one can say with confidence, however, is that the gains from inward investment by multinationals are reduced by the competition, and the attendant tax breaks, to get the investment.

From the viewpoint of the multinationals, this competition for them is a phenomenon that increases their share of the total economic gains flowing from investment in poor countries. Hence, it is not surprising that, while the multinationals have long asked for voluntary Codes (for instance, at the OECD, where a Code called the Multilateral Agreement on Investment was devised but ran into fatal opposition from rich-country NGOs), even mandatory provisions (proposed, by the European Union, for instance, at the WTO), to prevent the receiving countries from imposing restrictions on the multinationals that come in, they have resolutely opposed the imposition of any restrictions on tax breaks and subsidies to multinationals. This is an indefensible position for anyone who is setting the rules of the game for an efficient allocation of world investments, since both restrictions and artificial encouragement (through tax breaks) should be equally unacceptable.

\section{b. Large Companies and Small Countries}

In fact, the race to the bottom is part of the more general worry that critics have when negotiations for investment occur between large companies and small countries. It is assumed that this will lead to weak, poor countries yielding to unreasonable demands from strong, large corporations negotiating to come in. However, even weak countries can gain bargaining power by playing off one giant corporation against another; and they do. Thus a small country like Poland has recently chosen between Airbus and Boeing, both huge corporations and both in continuous and fierce competition that makes rip-offs of potential purchasers highly improbable. Enron was accused of having taken India for a ride just a few years ago, before the corporation self-destructed. But the problem was that India, because it was in a rush to get energy investments going rapidly, had foolishly failed to invite tenders and have Enron compete vigorously with other potential investors. ${ }^{3}$

\footnotetext{
${ }^{3}$ There were accusations of bribery by opposition parties in India and by some journalists, but they remained both implausible and unproven.
} 
In the end, the anti-corporations critics need to remember the chief lesson that economists faced in the 1930s with John Kenneth Galbraith's assertion that large corporations meant that there was monopoly power, and with the development of the new theories of imperfect competition among large firms, learnt: that the key to whether such monopoly power existed was to be found in effective barriers to entry, that contestable markets yielded 'as if' competition and little monopoly profits. Sheer size is misleading; giants also compete vigorously, cutting into monopoly power effectively, both in economic and political space.

But problems will arise where governance is weak, if not bad, and one must contend with the fact that rulers, politicians and bureaucrats may be bribed by corporations with deep pockets into creating monopoly profits at social expense and accepting terms and conditions that are detrimental to the host country's social advantage while the monopoly gains (or spoils) are split between the multinationals and the corrupted officials of the host country. There is no reason, however, to think that this 'joint rip-off' model is the typical one: after all, democracy, accountability and transparency are increasingly evident in poor countries as well, though we still have some distance to go. That transparency on the terms negotiated for entry by specific multinationals, and the enactment of the Code at the OECD (thanks to efforts by the US which had pioneered such legislation for US firms) to make bribes paid in host countries illegal, are the principal instruments to make the joint rip-off model less likely today.

\section{c. Political Intrusion}

Perhaps the greatest fear of the critics has been that multinationals intrude dramatically into the political space of host countries in nefarious ways. ${ }^{4}$ A classic example comes from South America though others can be cited. When Chile elected Salvador Allende, who began a decisive shift to the left in his policies towards foreign investment and economic policies in general, ITT drew a line in the sand, with the active assistance of the CIA and Dr Kissinger whose Chilean record of human rights abuses (or war crimes, as many contend today worldwide) has come under revived scrutiny. ITT and Pepsi are known to have played a role in the coup against this elected President of Chile and his overthrow and de facto assassination.

But the question for us is: are not such episodes much less likely, even highly improbable, today? This would indeed appear to be the case. The reasons are twofold. First, democracy has broken out in several underdeveloped countries, however imperfectly. Egregious political abuses surface because democracy

\footnotetext{
${ }^{4}$ For an early discussion of the political issue, see my 9th V. K. Ramswami Lecture, 'International Factor Movements and National Advantage', delivered in New Delhi, 1979; reprinted as Chapter 1 in my essays, International Factor Mobility, edited by Robert Feenstra (1983).
} 
permits diverse non-governmental groups, and individuals of conscience, to point the accusing finger at offending corporations and governments. Second, the accusing finger now has more salience in the age of television: Gorbachev uses troops in the Balkans, the CNN carries the pictures, and his moral standing collapses until he changes course and learns from his undoing.

These correctives seem to have diminished greatly the incidence of gross meddling in domestic politics by foreign multinationals. The real danger today lies instead in overreach against the multinationals, with demands that they in fact should meddle in domestic politics. Some NGOs today seem to accuse multinationals of neglect, rather than intervention, when it comes to advancing their own agendas.

\section{d. Exploitation of Workers?}

If any conviction strongly unites the critics of multinationals today, however, it is that they exploit workers in poor countries. At first flush, this sounds very strange since firms that create job opportunities should be applauded, no matter that their motivation in investing abroad is to make profits, not to do good. So, why do the critics get excited? Much of their ire has been aroused by their assumption that multinationals, so rich and with such deep pockets, pay such low wages. Then there is also the related assertion, including by the leaders of the anti-sweatshop movement on US campuses, that multinationals run sweatshops in poor countries. This accusation need not be based on payment of 'low' or 'inadequate' wages but on two alternative criteria: either that the multinationals violate explicit local laws on safety and other working conditions or that they do not conform to customary international law as typified by norms established in international conferences or through ILO conventions, for example.

That multinationals exploit workers in the poor countries by paying 'low' wages is the least persuasive charge. In fact, it comes close to being both nonsensical and contradicted by facts. The typical critique asserts that the output of the multinational, say a Liz Claiborne jacket, sells for $\$ 194.00$ presumably in Lord \& Taylor in Manhattan, New York, whereas the female worker abroad who sews it gets only 84 cents: exploitation is then 'obvious'. This precise estimate, and the inference of exploitation, were the central contention, in a Letter to the Editor in The Financial Times written in response to my defence of Nike in an op.ed. in the same newspaper, of Dr Eileen Applebaum, who held a senior professional position on the staff of the liberal-left think tank, The Economic Policy Institute in Washington DC. ${ }^{5}$ But there is surely no necessary relationship between the price of a specific product and the wage paid by a company that can be interpreted in this accusatory fashion.

\footnotetext{
${ }^{5}$ See Bhagwati (2000a); Applebaum, Letter to the Editor (5 May, 2000); and my reply, Letter to the Editor (11 May, 2000b), all in The Financial Times.
} 
Just for starters, for every jacket that succeeds, there are probably nine that do not. So, the 'effective' price of the jacket one must consider is a tenth of the successful jacket: only $\$ 19.00$, not $\$ 194.00$. Then again, owing to distribution costs, and in the case of apparel also the tariff duties, for sure, the price of a jacket almost doubles between landing in New York and finding its way to Lord \& Taylor's display hangers.

But that is not all. The relationship between output prices and wages can be anything, frankly, and may not reveal anything, generally speaking, of value. Thus, consider the diamond polishing industry in the town of Surat, India, which has witnessed rising prosperity ever since Surat has become a rival to Antwerp in this business. If the final price of the diamond in Paris is a million dollars, even a wage payment of $\$ 10.00$ an hour and a total wage payment to the worker of $\$ 1,000.00$ will appear minuscule as a fraction of the final price. But so what?

A possible question of interest may be whether Nike and other multinationals are earning huge monopoly profits while paying their workers only a competitive wage, and that these firms should share these 'excess' profits with their workers. But, as it happens, nearly all multinationals such as Liz Claiborne and Nike are in fiercely competitive environments. A recent Templeton College, Oxford, study of the profits performance of 214 companies in the 1999 Fortune Global 500 list shows a rather sorry performance, about 8.3 per cent on foreign assets, and even a decline to 6.6 per cent in 1998. Where is the beef that might be shared with workers?

So, let me turn differently to the question of 'low' wages: are the multinationals paying their workers wages that are below what these workers get in alternative occupations in what are really poor countries with low wages? This is virtually implied by the critics. We must ask; is this really true? Or are the multinationals actually paying higher wages than workers would get elsewhere, say from local firms in the industry or in alternative jobs? If the wages received are actually higher, even if 'low' (and reflective of the poverty in poor countries) according to the critics, surely it seems odd to say that multinationals are exploiting the workers they are hiring. Now, if there was slavery elsewhere and the workers were being whipped daily, as the Romans did with the galley slaves, then the fact that multinationals were whipping them only every other day would hardly turn away the critics. But wages are another matter, obviously. So, what are the facts on wage payments?

As it happens, several empirical studies do find that multinationals pay what economists now call a 'wage premium': they pay an average wage that exceeds the going wage, mostly up to ten per cent and exceeding it in some cases, with affiliates of US multinationals sometimes paying a premium that ranges from 40 to 100 per cent! ${ }^{6}$

\footnotetext{
${ }^{6}$ See Graham (2000).
} 
What about subcontracting by multinationals? There does not appear to be any significant evidence, when multinationals subcontract, that subcontractors pay lower than the going wage in domestic firms and in alternative jobs. It is likely, however, that the wages paid are closer to these alternatives; the wage premium is possibly negligible, if it obtains at all, in subcontracted work.

In both cases, whether there is direct employment at a wage premium by the multinationals or there is subcontracted employment at a negligible premium, these are only direct or proximate effects. By adding to the demand for labour in the host countries, multinationals are also overwhelmingly likely to improve wages all around, thus improving the incomes of workers in these countries.

But if the wage argument against multinationals must be dismissed, there is still the accusation that these corporations violate labour rights. Now, there are two different arguments here. One is simply that local labour laws are violated, on safety and other working conditions. This is the conventional view of 'sweatshops', not that they pay low wages (by which definition, since wages are necessarily low in poor countries, one would reach the absurd conclusion that all production in these countries is 'sweatshop output'), but that they violate local laws whatever they happen to be. There are serious difficulties with this critique, however.

First, it is highly unlikely that multinational firms would violate such laws and it is hard to find evidence that this is taking place in an egregious, even substantial, fashion. Typically, these sweatshops exist, like in the New York garment district (not in Guatemala, mind you), when illegal immigrant labour and lack of enforcement are the driving factors. I recall Secretary of Labour, Robert Reich, marching with a hapless TV celebrity, Kathy Lee Gifford, caught in the cross-currents of sweatshop accusation and denials, walking into the New York garment district to exhort against the violations of US legislation on working conditions; and imagine my surprise when I discovered that the entire United States had less than a dozen inspectors to do the job.

These sweatshops are typically small-scale, not multinationals. If the subcontractors who supply parts to multinationals, for example, are small shops, it is possible that they, like local entrepreneurs, violate legislation from time to time. But that raises the question: since the problem lies with lack of effective enforcement in the host country, do we hold multinationals accountable for anything that they buy from these countries, even if it is not produced directly by multinationals? But that is tantamount to saying that multinationals must effectively boycott purchasing anything that is produced and sold by countries where labour laws are not enforced, even when there is no formal boycott being imposed by the international community through invoking Article 7 at the United Nations, for example, or by the government of the country where the multinational is headquartered! That seems to be incoherent.

Second, such a position is also undemocratic since lack of enforcement may be explained by the fact that, in many poor countries, one encounters a bi-modal 
situation (i.e. there are two dominant practices) in regard to social legislation: either there are no laws or there are many, and excessively generous ones. The 'lack of enforcement' critique applies naturally to the latter situation. But then we must ask why the legislation is not enforced. The most likely reason is that there was no intention to enforce it in the first place. Often, extraordinarily expensive provisions are mandated simply because enforcement is going to be negligible. Thus, as the economist Henry Simon reminded us, progressive taxes were enacted to please the Democrats; and the loopholes were put in to please the Republicans. In the same spirit, countries like India have some of the most progressive, and expensive, legislation on the books concerning even minimum wages, but with no real intention to enforce it precisely because the cost of such mandates would be forbidding. So, the generosity of these provisions in the face of acutely limited resources is simply to feel good, that the legislators mean well but beyond that, alas ... ! In fact, the question one might well ask: why not then offer yet more generous benefits to the workers? I recall the Nobel laureate Robert Solow, a famous wit, being told that Harvard's highest salary was $\$ 150,000.00$ but that no one was being paid it, and then responding: in that case, why not say that the highest salary was $\$ 250,000.00$ ?

Indeed, often legislation may have also dated, and people may have changed their minds about its advisability, but the political battle to drop or modify it would be too expensive; so the legislation remains but no one seriously expects it to kick in. Thus, New Hampshire reportedly still has anti-adultery statutes on the books but they are dead like a skunk in deep snow.

But if multinationals are unlikely candidates for the accusation that they operate in significant numbers and with substantial lapses in violation of local labour laws on safety and working conditions, there always remains the almost impossible criticism that, no matter what the host country or home country laws, a multinational can be found in violation of what is called 'customary' international law. Except for off-the-charts behaviour such as employing slave labour or torturing workers in their employ, the problem with this type of criticism is that it is open-ended and becomes tantamount to harassment. In fact, I am of the view that, while the ILO and several NGOs have been pushing for the violation of 'core' labour standards as a violation of 'customary' international law, and this sounds reasonable, it is fraught with the danger that these general principles inherently leave too much ambiguity, opening the way for the persistent or powerful to harass corporations and poor countries which badly need investment by these corporations.

Thus, take the issue of the 'right to unionize', a critical right even within the 'core' labour standards. But how is one to cope with the fact that this right has several nuances and dimensions and that virtually all countries could be found in violation of it in some way? Thus, central to this right is the ability to strike: a union without an effective right to strike is a paper tiger. But, as a Human Rights Watch report, which concluded that 'millions of workers' in the United States 
are denied the right to unionise, noted, the Taft-Hartley law's provisions that allow hiring of replacement workers and discourage sympathetic strikes have badly crippled the ability to strike for half a century! $!^{7}$ So, are all corporations in the United States, which operate under this state-sanctioned violation of the most basic right to unionise, to be hounded and chastised?

The same could be said about the issue of gender discrimination, yet another core labour standard. There is no society today that is free from gender discrimination of some form, indeed of any form arguably. So, how does a broad statement of these 'core' rights, interpreted as 'customary' international law for the purpose at hand really help?

My view is that we need to assert these broad aspirational objectives but that, for purposes of assessing whether corporations in poor countries are to be condemned (and even litigated against, as is beginning to happen in US courts), ${ }^{8}$ we need to arrive at much narrower agreements on specific practices. For instance, on the right to unionise, we could reach agreement today on outlawing the killing of union leaders, but not on whether replacement workers can be hired, or firing of workers is allowed for economic or disciplinary reasons. Agreement could be reached, I suspect, on minimum safety provisions (e.g. the issuance, and enforcement of the use, of goggles by foundry workers working near blast furnaces) though not on rich-country, OSHA standards that are very expensive for poor countries. In short, just as there is virtual agreement that torture in the form of pulling nails out is unacceptable, but there is almost none on whether torture through use of isolation and significant deprivation of sleep should be permissible, it should be possible to find areas of agreement on narrowly specific practices which may be proscribed. We could then move on to bring in yet others. In short, start narrow and go broad. If you start broad, and seek to use NGOs and courts to object to narrowly specific practices, you are likely to create a world of subjective interpretations and unpredictable outcomes which will do harm rather than good.

The argument that 'customary' international law, interpreted broadly, can be used to say that multinationals are 'exploiting' workers in poor countries is therefore flawed, or at least open to serious criticism, except for very narrowly specified practices such as the use of slave labour, practices which virtually all nations condemn and many have outlawed. The anti-Nike and other campaigns, alleging that they do not pay a 'living wage' or do not have OSHA standards in their factories, are little more than assertions of what these specific critics would like a corporation to do, even when 'customary' international law and 'norms'

\footnotetext{
${ }^{7}$ Human Rights Watch (2000).

${ }^{8}$ The growing numbers of such lawsuits against US corporations in US courts by plaintiffs, mostly workers, who were employed elsewhere than in the US, are being listed in worldmonitors.com whose editor is Mina Samuels, whose own e-mail is mina@worldmonitors.com. I am indebted to Elliot J. Schrage for providing this reference.
} 
are invoked. It is perfectly possible and proper for others, equally motivated to do good, to say that these demands will harm rather than help workers in these poor countries, by making the inward flow of investment and jobs less likely by raising the cost of production, while rewarding further workers who are lucky enough to get jobs in foreign-owned corporations to begin with. If so, these critics are themselves in unwitting violation of perhaps the most important 'core' value: that globalisation, and multinationals, should help the working class, not harm it!

Economists have also tried to get at this question from another angle. They have asked: is there evidence that multinationals are partial to investing in poor countries which have poor protection of workers' rights to unionise and to enjoy a safe workplace? Consider first, however, whether wages matter. Of course, one needs to be careful and not just look at wages; they must be adjusted for labour productivity differences; if they are not, higher wages may simply reflect higher productivity and therefore not be a deterrent to inward investment. Studies that do this, though they are not focused on poor countries but rather on investment flows among rich countries or among different states within the United States, show that (productivity-adjusted) wages do matter. But other evidence suggests that this is only one of many factors determining location decisions by multinationals. ${ }^{9}$

But what about non-wage matters? Interestingly, cross-section analysis of the outward investment by US corporations shows that the more ILO workers' rights conventions are ratified by a country, the greater tends to be its share in US investment. ${ }^{10}$ Of course, the United States has in truth a better record on workers' rights, no matter how defined, than China; but China has ratified more conventions than the US because the US political and legal scene requires, whereas the Chinese one does not, that ratifications lead to real obligations. So, ratifications are not a good guide to what protection exists for workers in reality. Analysts at the ILO have also found that higher unionisation rates are associated with higher investment inflows, whereas fewer 'episodes' of repression of rights of collective bargaining and association also go with higher inflows. ${ }^{11}$ In short, the crosssection evidence, which is often evidence of association rather than of cause and effect and must be taken as little more than indicative, suggests that multinationals do not go streaking to where labour rights are ignored or flouted. If true, this suggests that the notion that multinationals, by moving to where workers' rights are violated, encourage their violation by the poor governments seeking to attract them, is not empirically supported.

9 These studies are reviewed in Brown et al. (2002, pp. 24-27).

${ }^{10}$ Cooke and Noble (1998).

11 Kucera (2001). 


\section{BAD DOMESTIC POLICIES AS A CAUSE OF HARMFUL EFFECTS}

So, the conventional criticisms of multinationals as harmful agents to poor countries and to their workers are not persuasive when confronted with the available evidence. But there are also conventional caveats about the possible harmful consequences of multinationals which economists have warned against. But these follow from the fact that domestic policies, which they could change, are the source of the problem. Or, as the Oxford economist Ian Little has put it well, direct foreign investment is as good or as bad as your own policies.

Perhaps the most interesting caveats, with empirical support, relate to the inflow of multinationals in the presence of high tariffs and other trade barriers. In fact, in most poor countries, in the earlier anti-globalisation era in the 1950s and 1960s when outward integration was feared, multinationals were also discouraged as part of what was called an 'import substitution' (IS) or 'inward-looking' approach to the world economy. But some countries actually used high trade barriers as a way to get multinationals to come in and invest. The tactic was to tell a multinational that was selling its products, say radios in your country: we will no longer allow you to sell the radios here and you will have to set up production facilities here to be able to sell your products. This tactic, used in the context of the IS developmental strategy, came to be known as one that led to 'tariff-jumping' inward foreign investment by the multinationals.

The problem with this type of investment inflow was that it usually led to heavy dependence on imports of components. Faced with this tactic, firms tried to get by with as little production in the country and import of the rest from more efficient factories elsewhere. So, while a finished car could not be imported, the car manufacturing firm often found it possible to get away by importing nearly all of it and just adding the chrome and bumper to it in an assembly plant in the country! So, the industrial development became acutely 'import-intensive' in economists' jargon: a little value added would necessitate an enormous import burden. So, the multinationals were often reduced to a battle with the governments: they wanted to assemble as much as they could; the governments wanted to assemble as little as they could. The resulting acrimony in these IS-strategy economies, and the inefficiencies that follow, are well illustrated in the journalist Jim Mann's account in his beautifully documented book, Beijing Jeep, of what happened when the American Motor Corporation (AMC) went into China to produce Jeeps for the domestic market. The AMC just wanted to position itself in the Chinese market with as much import of the knockdown car as possible; the Chinese wanted full-blooded production in Beijing instead and, to make matters worse, they wanted AMC to spend resources to adapt the Jeep for the Chinese army's use, a commercially uninteresting proposition for AMC. Evidently, the IS model for attracting investment was fraught with difficulties. ${ }^{12}$

\footnotetext{
${ }^{12}$ See Mann, Beijing Jeep (1989), and my review of it in The New Leader (1989).
} 
But, equally important, economists soon realised that this strategy was also likely to reduce the social returns to the inward flow of direct investment to the point where it might actually immiserise, rather than enrich, a country. This is because the increased import intensity of the process might well lead to losses from the deterioration of the terms of trade since exports had to increase to pay for increased imports and that could reduce earnings from exports; and these indirect or induced losses could outweigh any direct gains from the inflow of investment. But the immiseration could also arise since the investment-inducing 'tariff jumping' trade barriers impose a cost; and this too could outweigh any direct gains from the attracted investment. ${ }^{13}$

But where the 'export promoting' (EP) or outward-oriented trade strategy was adopted, as indeed it was in the Far Eastern economies, the foreign firms came to produce, not for the domestic market, but for world markets. Thus, just as such EP strategy was favourable to growth, and the social returns from domestic investment were substantial, so were the social returns to foreign investment. ${ }^{14}$ South Korea did not use inward foreign investment as a principal component of her overall developmental strategy, following the Japanese model. But Taiwan, Hong Kong and Singapore certainly did. And so did China since her opening up to trade in the 1980s when the IS variety of Beijing Jeep investment was replaced by the enormous EP type of investment in the four coastal provinces whose enormous export success translated into China's impressive transformation in the two decades since.

\section{POWERFUL GOOD EFFECTS}

But if the harmful effects can be removed by policy changes suggested by experience and be replaced by good effects instead, economists can also note other good effects that multinationals can bring in their wake. Perhaps the chief such good effect is what economists call 'spillovers'. Do domestic firms benefit when multinationals with better technology and management practices establish themselves in an industry because they learn productivity-enhancing techniques from these firms, for example? Different channels through which such diffusion may occur can be identified. Thus, managers may learn by observing or hearing about better management practices. Or they may learn them when employed by the multinationals, then transferring them to local firms when they take jobs with them or start their own domestic firms instead. Such diffusion may also happen with production workers who learn better discipline, for example, when employed by the foreign firms and then take it with them to local firms where their experience is translated into a better workforce.

${ }^{13}$ There is a huge literature on the possibility of immiserising foreign investment, a possibility noted by several authors including myself, but beautifully demonstrated by the economists Carlos Diaz Alejandro and Richard Brecher in a classic article in the Journal of International Economics.

${ }^{14}$ See again Balasubramanyam et al. (1996). 
That such diffusion occurs and therefore benefits the local firms and hence the host country has been the conventional view among economist students of multinationals for some time. It owes partly to early studies which showed that the growth rate of productivity in industries with a greater share of multinational output was higher. Many studies supported this, even when the growth of productivity in domestic firms was sharply isolated and only this was related to the inflow or presence of multinationals. ${ }^{15}$ In recent years, there has been a veritable explosion of such studies. In particular, economists have probed the channels through which the spillover effects could operate. Thus, Görg and Strobl (2005), using firm-level data for a sample of manufacturing firms in Ghana, have demonstrated that spillovers occur through movement of labour because workers trained in multinationals move to local firms, often new start-ups, taking with them the knowledge acquired when they worked for the foreign firm. Again, analysis of electronics and engineering sectors in the United Kingdom has underlined that diffusion tends to be greater for domestic firms within the same industry and region. ${ }^{16}$ There is also evidence, from the analysis of firm-level data in the United Kingdom, that local firms may learn to export from multinationals, through information spillovers, demonstration effects and increased competition. ${ }^{17}$

While a few studies show zero spillovers, it is certainly possible that there may even be harmful spillovers: local entrepreneurship, for example, may be destroyed or inhibited. The fear that large multinationals would drive small local firms into extinction and cripple domestic entrepreneurship is widespread among the critics of multinationals. This is best reflected in the cartoon I once saw, of a tiny vendor selling hot dogs under a giant skyscraper owned by a manufacturer of packaged foods. But that cartoon also showed the weakness of the argument: the two manage to co-exist perfectly well! In short, once differences in quality and in the customers targeted are taken into account, there is room for big and small. The fears are grossly overblown, to say the least; none of the econometric studies of spillovers have turned up significant evidence of harmful spillovers to date. (For a comprehensive review of the evidence see Görg and Greenaway, 2004.)

\section{CORPORATE SOCIAL RESPONSIBILITY}

If corporations help rather than harm poor countries and their workers, then the bottom seems to be knocked out of the case for corporate social responsibility

\footnotetext{
${ }^{15}$ Several of these early studies, including the very first by Jorge Katz which used Argentine data, have been reviewed by Magnus Blomström and Ariel Kokko of the Stockholm School of Economics in various publications.

${ }^{16}$ Girma and Görg (2002).

${ }^{17}$ Greenaway et al. (2004).
} 
that is based on the conviction that the harm they do must be offset by the assumption of compensatory social responsibility. It would appear, therefore, that the true, indeed the only, compelling reason for corporations to assume social responsibility is that it is the good thing to do. For in so doing, they will enhance the social good that their economic activities promote when they invest in these developing countries, and for which there is now much evidence. Indeed, this act of altruism is precisely what characterised many of the socially committed families that made fortunes in trade and industry: the Dutch burghers (of Simon Schama), the Jains of Gujarat in India, the Quakers (such as the Wilberforces that led the fight against slavery), the Jews (such as the Rothschilds). With the rise of the corporations delinked from families, there is now a growing perception that they too, and not just the floating crowd of shareholders in their personal capacities, should commit themselves to such altruism, playing their role in adding to the public good as each corporation best sees fit.

In creating the architecture of corporate social responsibility, however, we must walk on two legs. One leg has to be this altruistic one, which deals with what corporations should do. But the other leg must deal with regulation that defines what corporations should not do. In fact, once this is recognised, it is apparent that we need three complementary approaches.

\section{a. 'Social Norming'}

Secretary-General Annan's Global Compact at the United Nations first proposed by him in Davos three years ago, is what economists call a 'social norming' proposition. By signing on to it, corporations agree to uphold certain broad values such as human rights, which of course include our rights as workers, as consumers, as voters, as children and as women. The Compact has now been endorsed by several leading NGOs such as Amnesty International, and by unions such as the ICFTU as well. However, as it has no monitoring, certification and enforcement mechanism, it has been rejected by some unions and NGO activists. But they are missing the point.

The very act of signing on to such a Compact focuses the signatory corporations, as well as potential critics, on what they do and plan to do to achieve progress toward the objectives which consist of widely shared, and internationally affirmed, social values broadly stated (such as the removal of gender discrimination and child labour). Given the general nature of the Compact's objectives, however, the exact steps they take must surely be left to the corporations, working with the democratic countries in which they operate.

For instance, signatory corporations operating in the United States - where, it may be recalled, a recent Human Rights Watch report has found that 'millions of workers' in nearly all industries are denied full freedom to associate and form unions (largely but not exclusively because of restrictions that make it difficult 
to organise strikes effectively) - can be expected to follow national legislation and act within their national rights. They would, for example, exercise their right to hire replacement workers freely, even though that helps cripple the right to strike. But they would be expected to reduce wage discrimination against women within the same institutions of hire because the US accepts that objective explicitly and enforces it.

The complexity of the issue is illustrated further by the fact that there are both narrow and broad definitions of gender discrimination with regard to equal pay. What US corporations do with regard to ensuring equal pay for women to ensure conformity to 'workers' rights' objectives will depend, therefore, on the prevalent US legislation. Thus, what 'socially responsible' American corporations do in the US may well differ from what Sweden or India accepts as a sensible way to proceed, although all three nations accept the general concept of 'granting the freedom of association' and 'eliminating gender discrimination'.

Despite this inevitable, and indeed desirable, diversity of detail, the Compact will help diffuse good practices in a flexible fashion. Once corporations with reputations to protect have signed on, they are in the public view. Pressure to make some progress, no matter how diverse and situation-specific, will arise, leading the corporations to move in one way or another towards the norms they have affirmed.

The same can be said of a growing number of codes developed by industry associations. They are critiqued as cop-outs, as 'dodges' designed to mislead and misdirect critics by pretended action. But these criticisms seem to me to miss the dynamics of social norming which promises more over time than is immediately delivered.

\section{b. Voluntary Codes}

We now also have several 'social accountability' codes that are offered by organisations that have been set up specifically to propagate corporate social standards. Leading examples include the pioneer, the New York-based SA8000 (on whose board I have served), and the UK-based Ethical Trading Initiative, the Washington-based FLA and others. Unlike the Global Compact, they involve specific obligations and, equally important, monitoring prior to and after certification. Decertification can also follow: SA8000 has been known to decertify factories. These codes are voluntary; they can be ignored; but once signed on to, they entail well-defined obligations.

The proponents of each voluntary code would like to have their own as the only one available. But this would be fundamentally wrong. The codes can and do contain so many different requirements that diversity is desirable. In fact, since virtually all codes currently available are from developed countries, I believe it is essential that some be drafted by developing countries. That would bring very different perspectives into the fray. For example, there is a great push for a 
living-wage requirement in nearly all of these codes. But this, according to many intellectuals and NGOs in developing countries, is misguided since, as already discussed earlier, multinationals typically pay a premium wage to their workers: why raise that further by pretending that workers are being exploited because they are not earning even more? A code that explicitly excludes a living-wage requirement but includes other stipulations should also be available. But it will likely not come from the developed world.

The element of choice and the need to keep developing country perspectives in view are issues that have escaped the anti-sweatshop movement on US university campuses. In fact, I believe that the currently available codes over-emphasise developed country perspectives on issues such as workers' rights and neglect developing country perspectives. The codes reflect a certain degree of paternalism as well as the deep influence of Western labour unions, whose own perspectives are often coloured by the increasingly fierce competition from poor countries.

These issues have surfaced in the context of the anti-sweatshop agitation on American university campuses to define social responsibility by textile firms abroad and to exclude campus contracts for supply of apparel etc. if these firms do not sign on to specific codes. Several economists, organised under the Academic Consortium of International Trade Scholars (ACIT) formed recently by myself and others at Michigan University, joined the debate on these questions and had some success in bringing them to the forefront. This was not done with a view to rejecting the notion of social responsibility, but rather with a view to bringing reasoned debate, and needed diversity, to the definition of social responsibility.

\section{c. Mandatory Codes}

Complementing the Global Compact and voluntary codes is the suggestion of national mandatory codes which would extend to operations abroad by a nation's multinationals the rules and regulations that define at home what the corporations cannot do as good citizens.

These mandatory national codes will naturally vary across nations (because different nations will have different ideas and laws concerning what is allowable and what is not) whereas the voluntary codes are obviously uniform worldwide. I suggested such a mandatory code for American firms operating in Mexico over a decade ago in the New York Times, in the context of the NAFTA debate: it would ask American firms abroad to 'do in Rome, not as Romans do, but as New Yorkers do'. ${ }^{18}$ In short, US firms must abide abroad by the basic principles that are expected at home.

Thus, under this approach, if a US firm had been in South Africa when apartheid was practised, it would have been subject to the US mandate not to practise

18 'American Rules, Mexican Jobs', New York Times (24 March, 1993). 
the same policy. Or if Mexico did not have legislation forbidding the dumping of mercury into its waters, American firms would be expected by the US not to take advantage of that. Yes, some American firms will move to the Bahamas to escape these codes, but then, if they get into political trouble, the US marines or US diplomatic muscle will not be available to help them either.

Such mandatory national codes can extend to more specific environmental and 'decent-work' (minimal safety and dignity) provisions. Empirical evidence strongly suggests that many big firms, which account for the bulk of foreign investment in developing countries, generally abide by such provisions anyway. Why not then allay concerns over a race to the bottom and put some of these provisions into the mandatory national codes?

Will these diverse mandatory codes imply that a universal mandatory code is to be denied? On the contrary. As these national mandatory codes come into play, the mere juxtaposition of good and bad practices will create pressures over time for convergence to good practices, given civil society and democracy today. The convergence to universal mandatory codes, as with the recent Tobacco Treaty at the WHO, came after decades of national legislations where some nations moved ahead of others, while the laggards caught up under the pressures generated by the good practices of the pioneers. The reverse model of starting, rather than ending, with uniform and universalist mandatory codes seems to be unrealistic except for practices that are truly off the charts today, such as slavery and forced labour.

A tapestry woven in three colours, one of social norming codes, another of a multiplicity of voluntary codes, and a third of diverse mandatory national codes, would then appear to define a nuanced and desirable approach to the question of social responsibility by global corporations today. They would put multinationals, unfairly accused of predation, into a yet better position as institutions that mightily advance the economic and social good in the countries they invest in.

\section{REFERENCES}

Applebaum, E. (2000), 'Unsuitable Wages Comparison', Letter to the Editor (Financial Times, 5 May). Balasubramanyam, V. N., M. Salisu and D. R. Sapsford (1996), 'Foreign Direct Investment and Growth in EP and IS Countries', Economic Journal, 106, 434, 92-105.

Bhagwati, J. (1983), 'International Factor Movements and National Advantage', in R. Feenstra (ed.), International Factor Mobility (Cambridge, MA: MIT Press).

Bhagwati, J. (2000a), 'Mistaken Presumption of Labour Exploitation', Letter to the Editor (Financial Times, 11 May).

Bhagwati, J. (2000b), 'Nike Wrongfoots the Student Critics' (Financial Times, 2 May).

Bhagwati, J. (2004), In Defense of Globalization (Oxford: Oxford University Press).

Brown, D., A. Deardorff and R. Stern (2002), 'The Effects of Multinational Enterprises on Wages and Working Conditions in Developing Countries' (Mimeo, University of Michigan, 11 March).

Cooke, W. N. and D. S. Noble (1998), 'Industrial Relations Systems and US Foreign Direct Investment Abroad', British Journal of Industrial Relations, 36, 4, 581-609. 
Diaz Alejandro, C. F. and R. Brecher (1977), 'Tariffs, Foreign Capital and Immiserizing Growth', Journal of International Economics, 7, 4, 317-22.

Girma, S. and H. Görg (2002), 'Foreign Direct Investment, Spillovers and Absorptive Capacity: Evidence from Quantile Regressions' (Leverhulme Centre, University of Nottingham, 2002/14).

Görg, H. and D. Greenaway (2004), 'Much Ado About Nothing? Do Domestic Firms Really Benefit from Foreign Direct Investment?', World Bank Research Observer, 19, 2, 171-97.

Görg, H. and E. Strobl (2005), 'Spillovers from Foreign Firms Through Worker Mobility', Scandinavian Journal of Economics, 107, 693-709.

Graham, E. M. (2000), Fighting the Wrong Enemy: Antiglobal Activists and Multilateral Enterprise (Washington, DC: Institute for International Economics).

Greenaway, D., N. Sousa and K. Wakelin (2004), 'Do Domestic Firms Learn to Export from Multinationals?', European Journal of Political Economy, 20, 4, 1027-43.

Human Rights Watch (2000), Unfair Advantage: Workers' Freedom of Association in the United States under International Human Rights Standards (August).

Kucera, D. (2001), The Effects of Core Worker Rights on Labour Costs and Foreign Direct Investment: Evaluating the Conventional Wisdom (Geneva: International Labour Organisation).

Mann, J. (1989), Beijing Jeep (New York: Simon \& Schuster).

New York Times (1993), 'American Rules, Mexican Jobs' (24 March). 